\title{
Composition of camel milk and evaluation of food supply for camels in Uzbekistan
}

Valeriy V. Pak ${ }^{1 *}$, Olim K. Khojimatov ${ }^{2}$, Gulnara J. Abdiniyazova $^{3}$ and Elena B. Magay ${ }^{4}$

\begin{abstract}
Background: In Uzbekistan, local people consumed camel milk products since ancient time. Camel milk is a source of energy and nutrients which are consumed as raw or fermented products and also provides various potential health benefits for human.

Methods: The data were collected during 2016-2018 by expeditions in desert and semi-desert regions of Uzbekistan. Three hundred sixty sheets of plants have been collected from those regions. Forty-two samples of raw camel milk were collected at two periods of the year: 21 samples during summer (June, July, and August) and 21 during winter (December, January, and February).

Results and discussion: Analysis of the composition of camel milk samples revealed the particular richness of camel milk in protein and fat content. Average values of protein and fat were found as $4.04 \pm 0.36 \% \mathrm{~W} / \mathrm{v}$ and $4.89 \pm 0.26 \%$ $\mathrm{W} / \mathrm{v}$, respectively. Analysis of the composition of camel milk showed that protein, fat, and dry matter contents were comparatively lower in the summer period. Also, it was found that the average values of all components decreased from December to February and had a tendency to grow from June to August. This finding suggests a seasonal variation in available food supply. Investigation of an available fodder flora revealed that a fodder base consists of around 300 plants. Analysis of plant species revealed that 30 plants were widely used in traditional medicine.

Conclusion: Our results suggested that the healing benefit of camel milk can be connected with higher content of proteins including the various protective proteins and with secretion of the bioactive compounds from plants with medicinal properties via food.
\end{abstract}

Keywords: Camel milk, Composition of camel milk, Food supply, Medicinal plants, Uzbekistan

\section{Introduction}

Camel milk and its based products are considered to play an important role in daily food of rural communities in Asia, Africa, and the Middle East. For desert people, it is a source of energy and nutrients which are consumed as raw or fermented products $[1,2]$. A distinctive feature of camel from any other domestic livestock species is that camel can produce more milk for a longer period of time in arid zones. The lactation period ranges from 12 to 18 months [3].

Many studies reported that camel milk provides various potential health benefits including angiotension I-converting enzyme-inhibitory activity,

\footnotetext{
* Correspondence: pakvaleriy@yahoo.com

${ }^{1}$ Department of Organic Synthesis, Institute of the Chemistry of Plant Substances, Building 77, Acad. Kh. Abdullaev Str., Tashkent, Uzbekistan 100170

Full list of author information is available at the end of the article
}

hypocholesterolemic effect, hypoglycemic effect, and antimicrobial and hypoallergenicity effects $[4,5]$. As evaluation of the healing properties, several studies were conducted regarding the camel milk composition, physicochemical characteristics, functionality, microbiological quality, and prevalence of some bacterial pathogens $[6,7]$. It should be noted that fermentation of camel milk occurs naturally without prior heat treatment and without addition of starter cultures. Also, the absence of salmonella in raw camel milk presents a certain interest [8].

Uzbekistan is located in Central Asia. Over half of the Uzbek territory is covered by desert: the Kyzylkum, Ustyurt desert plateau, and Aralkum formed on the former bottom of the Aral Sea (Fig. 1). Kyzylkum is a huge desert in Central Uzbekistan, which stretches between the Amu Darya and Syr Darya on the territory 


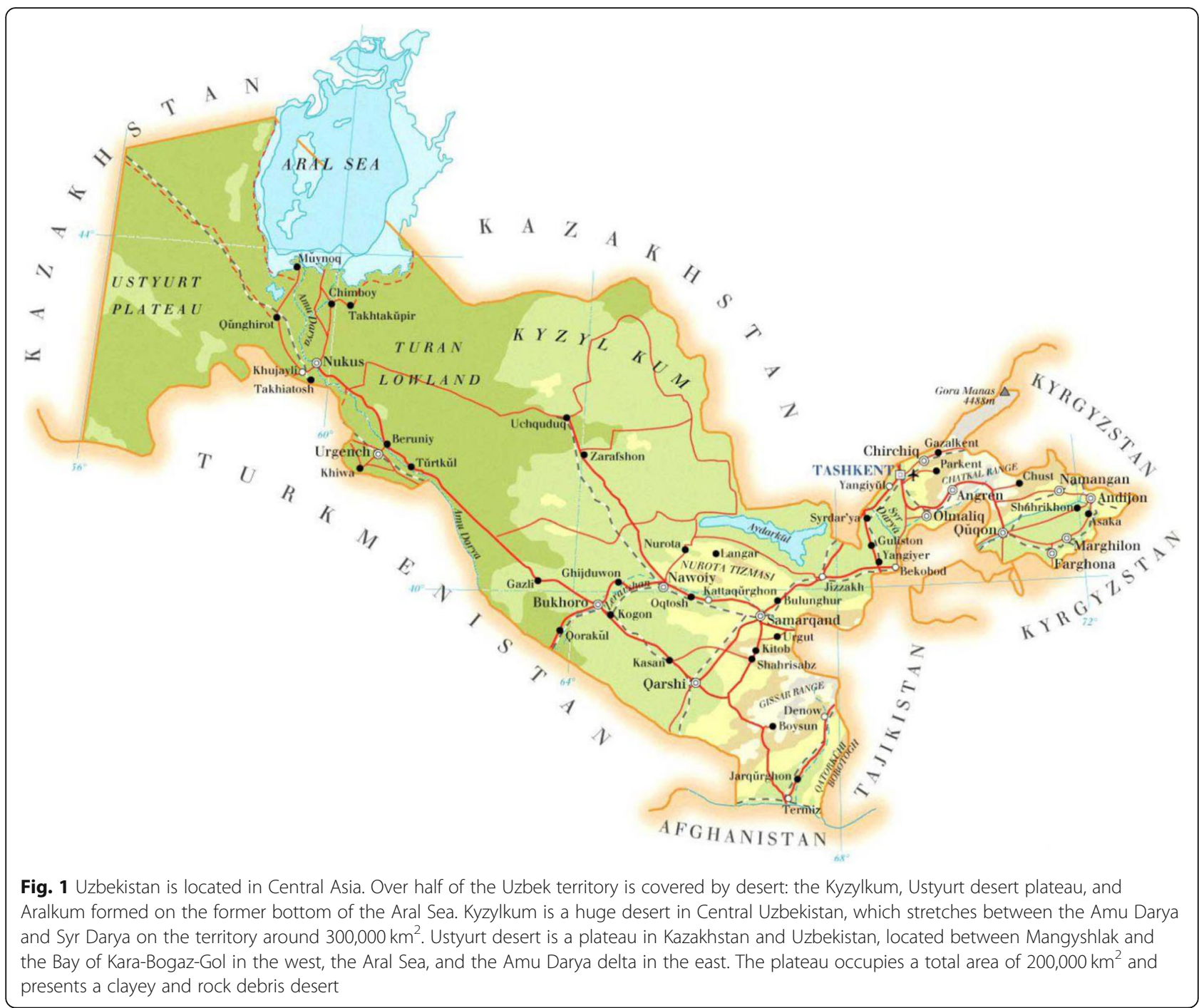

around $300,000 \mathrm{~km}^{2}$. Ustyurt desert is a plateau in Kazakhstan and Uzbekistan, located between Mangyshlak and the Bay of Kara-Bogaz-Gol in the west, the Aral Sea, and the Amu Darya delta in the east. The plateau occupies a total area of $200,000 \mathrm{~km}^{2}$ and presents a clayey and rock debris desert.

The difficult climatic conditions in the arid areas have contributed to a special approach to diet and which have been established in many generations of locals. Along with livestock such as horses, cows, donkeys, goats, and lambs, camel is the animal to adapt the most to such conditions. A camel, which was born and raised in the desert, can significantly lose the weight of its body under the influence of the sun, but, unlike other animals, does not lose its good condition. It can replenish the supply of liquid by drinking up to $180 \mathrm{l}$ of water in one time and continue to stay quietly under the sun. In this way, the camel restores its shape and again saturates the body with the necessary moisture.
One of the first sources to describe products derived from camels was a "Canon", which was written in 10121024 by Abu Ali Ibn Sina (Avicenna). Abu Ali Ibn Sina (980-1037) was the brilliant scientist of the Middle Ages. He was born on the territory of Uzbekistan, in the village of Afshona, near Bukhara. His legacy is 456 books; among them, 62 books were about medicine.

He wrote that any kind of milk causes blockages, especially in the liver, except for camel milk due to "low degree of curd" and due to the cleaning property of its water part. Cow milk has a lot of fat, sheep milk has "high degree of curd," and camel milk has little fat and "low degree of curd," which further follow mare and donkey milk. Camel milk has salinity. It was observed that camel milk is severely delayed in the stomach and in the upper parts of the abdominal cavity, longer than any other milk. Camel milk helps asthma and shortness of breath. Milk does not cause blockages in the liver, and whey from curd is useful against jaundice. Milk, 
with the exception of camel milk, is harmful to the spleen and liver of patients who need a light diet. Camel milk is useful in many diseases of the spleen and liver and "moisturizes" the liver. It is very useful in hydrops, the excessive accumulation of serous fluid in tissues. Also, camel milk excites appetite. A description has been given of the integrated use of camel milk with other ingredients for the treatment of ulcers, tumors, etc.

The continued tradition of camel milk consumption and the manufacture of products based on it remain relevant today in daily life. In Uzbekistan, local people consumed camel milk products since ancient time as valuable source of nutrients. Along with consumption of camel milk, they prepare "Shubat." This camel milk product has various names in different parts of the world. It has substantial amounts of ethanol that is produced during milk fermentation [9]. It is popularly known as a beverage which is white, snappy due to its $\mathrm{CO}_{2}$ production, and has a high degree of sourness. Another fermented milk product is known as "Qurt" (Fig. 2). It has a solid texture and salty taste and can be kept for a long time. Traditionally, "Qurt" is produced from a kind of strained yogurt called "Chaka" or "Suzma." It is obtained by drying "Qatiq," a local yogurt variety. The water is removed from this product and what remains is "Qurt" which is further dried to obtain a solid texture. Also, spices can be added to it. All procedures take 3-5 days in summer or 15-20 days in winter. In ancient times, it was the main protein source for people living in the desert area of Uzbekistan.
In Uzbekistan, two species of camels can be seen: a single-humped camel (Camelus dromedarius) and the two-humped camel, or a Bactrian (Camelus bactrianus). The single-humped camels is seen more often. It was proposed that probably feeding can explain the specific healing properties and composition of the camel milk [10]. The camels are grazed by changing location of the pastures. In flora of arid and semi-arid regions of Uzbekistan, more than 1000 species of vascular plants are growing $[11,12]$. The majority of those plants have medicinal properties and found to have an application in traditional medicine.

The medicinal value of camel milk for the treatment of gastritis, asthma, stomach discomfort, tuberculosis, fever, urinary problems, and hepatitis were described in the study [5]. From these points of view, the presented research is focused on study of food supply for camels.

\section{Materials and methods Plant sampling}

In this study, the data were collected during 2016-2018 by expeditions in desert and semi-desert regions of Uzbekistan which are located in Karakalpakstan. It is now mostly desert and occupies the whole northwestern end of Uzbekistan with an area of $164,900 \mathrm{~km}^{2}$. During the field studies, the species of wild-growing plants which are eaten by the camels were investigated. Three hundred sixty sheets of plants have been collected from those regions, and these are stored as herbarium

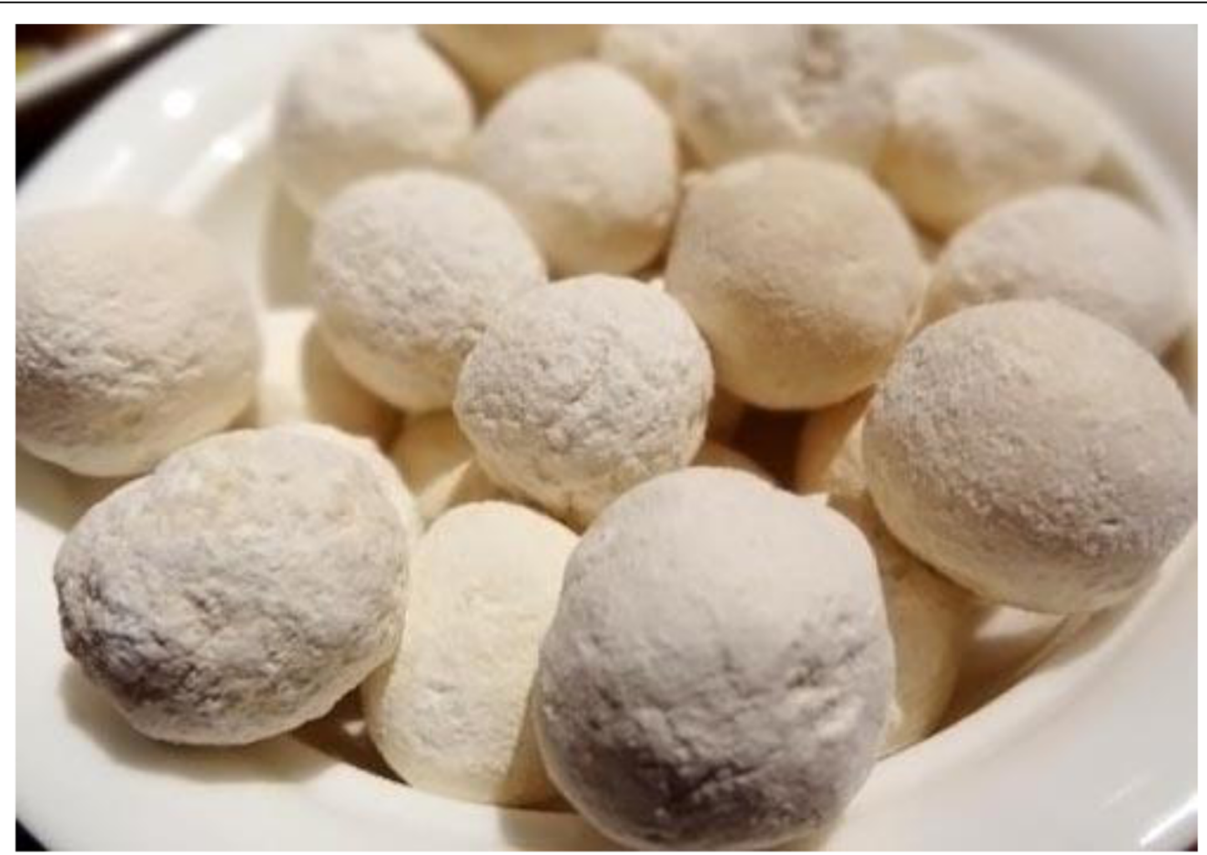

Fig. 2 Qurt has a solid texture and salty taste and can be kept during a long time. Traditionally, "Qurt" is produced from a kind of strained yogurt called "Chaka" or "Suzma." It is obtained by drying "Qatiq," a local yogurt variety. The water is removed from this product and what remains is "Qurt" which further dried to obtain a solid texture 
Table 1 Composition of camel milk by the sampling period

\begin{tabular}{|c|c|c|c|c|c|c|c|}
\hline \multirow[t]{2}{*}{ Component } & \multicolumn{6}{|c|}{ Content, \%w/v } & \multirow{2}{*}{$\begin{array}{l}\text { Average } \\
\% \mathrm{w} / \mathrm{v}\end{array}$} \\
\hline & December & January & February & June & July & August & \\
\hline Fat & 5.2 & 5.15 & 5.01 & 4.57 & 4.61 & 4.82 & 4.89 \\
\hline Protein & 4.47 & 4.33 & 4.27 & 3.62 & 3.71 & 3.82 & 4.04 \\
\hline Lactose & 4.85 & 4.25 & 3.88 & 4.01 & 4.45 & 4.25 & 4.28 \\
\hline Ash & 0.88 & 0.9 & 0.75 & 0.69 & 0.68 & 0.73 & 0.77 \\
\hline Dry matter & 15.56 & 14.6 & 14.4 & 13.65 & 12.64 & 12.83 & 13.95 \\
\hline
\end{tabular}

specimens in the Central Herbarium of the Institute of the Botany in the Uzbekistan Academy of Sciences and Research Institute of Natural Sciences, Karakalpakstan branch of the Academy of Sciences of Uzbekistan.

\section{Milk sampling}

Milk samples were taken from milk mixture collected from breeders of the different regions of Karakalpakstan. A total of 42 samples of raw camel milk were collected at 6 different periods of the year: 21 samples during summer (June, July, and August) and 21 during winter (December, January, and February). The collected milk was obtained by hand milking of camels in the field condition. The fresh samples of camel milk were divided on two portions. The first portions were used to test the physical-chemical analysis such as $\mathrm{pH}$, acidity, and density. The second ones were kept in cold conditions for milk content analysis.

\section{Physicochemical analysis of camel milks}

The $\mathrm{pH}$ of camel milk samples was measured by using a digital $\mathrm{pH}$ meter (FiveEasy ${ }^{\mathrm{Tm}} \mathrm{pH} / \mathrm{mV}$ Meters, Mettler Toledo, Greinfensee, Switzerland), and their titratable acidity was determined based on the accepted methodology in Association of Official Analytical Chemists (AOAC) [13]. Sample densities were measured by using a digital density meter (Mettler Toledo 30 PX, Greinfensee, Switzerland). For determination of dry matter, fat content, lactose, and ash, AOAC methods were also used [13]. Protein content was determined by the standard Kjeldahl method [13]. Each value represents the results of triplicate experiments.

\section{Results and discussion}

Many factors have an influence on the composition of camel milk such as the difference of geographical origin, physiological stage, feeding conditions, and seasonal variations [10]. In accordance with the study, the average amount of components of camel milk was found as protein-3.4\%, fat $-3.5 \%$, lactose $-4.4 \%$, and ash $-0.79 \%$, while water covers $87 \%$ [4].

The obtained results of physicochemical parameters and composition of the 42 samples of raw camel milk showed that values of the $\mathrm{pH}$ and titratable acidity ranged from 6.22 to 6.54 and 0.15 to $0.18 \% \mathrm{w} / \mathrm{v}$, respectively. The average values of milk sample density were calculated as $1.029 \pm 0.003 \mathrm{~g} / \mathrm{cm}^{3}$ in winter and $1.022 \pm$ $0.003 \mathrm{~g} / \mathrm{cm}^{3}$ in summer season. The frequency of water intake by camels had an influence on camel milk densities [7]. Average values of the component composition of camel milk samples were found as protein-4.04 \pm $0.36 \% \mathrm{w} / \mathrm{v}$, fat-4.89 $\pm 0.26 \% \mathrm{w} / \mathrm{v}$, lactose $-4.28 \pm 0.34 \%$ $\mathrm{w} / \mathrm{v}$, ash $-0.77 \pm 0.09 \% \mathrm{w} / \mathrm{v}$, and dry matter-13.95 \pm $1.12 \% \mathrm{w} / \mathrm{v}$ (Table 1). Estimation of values of fat, protein, lactose, and dry matter in camel milks by an analysis of variance revealed that all results were statistically significant $(p$ value $<0.05)$. The results in Table 1 showed that fat, proteins, and dry matter contents of camel milk samples were comparatively lower in summer period (June-August). This finding of seasonal variation of camel milk composition was in accordance with a number of studies $[14,15]$. Comparison of the average values of dry matter in winter and summer season revealed an inverse relationship between dry matter in camel milk and water intake by camels. It was found that the

Table 2 Main diet of camels on seasons

\begin{tabular}{|c|c|c|}
\hline №. & Season & Plants \\
\hline 1 & Spring & $\begin{array}{l}\text { Bromus tectorum L., Poa bulbosa L., Chorispora tenella (Pall.) DC., Artemisia terrae-albae Krasch., A. pauciflora Web., Astragalus } \\
\text { villosissimus Bunge, Kraschennikovia ewersmanniana (Stschegl ex Lonsinsk.) Grub., Kraschennikovia ceratoides (L.) Gueldenst. }\end{array}$ \\
\hline 2 & Summer & $\begin{array}{l}\text { Morus alba L., M. nigra L., Peganum harmala L., Chorispora tenella (Pall.) DC., Astragalus villosissimus Bunge, Bromus tectorum L., } \\
\text { Salsola richteri (Moq.) Kar. ex Litv., Salsola paletzkiana Litv., Ephedra distachya L., Andrachne rotundifolia C. A. Mey., Dodartia orientalis } \\
\text { L., Cousinia sp., Artemisia terrae-albae Krasch, Smirnowia turkestana Bunge, Alhagi pseudalhagi (Bieb.) Fisch., Chenopodium album L., } \\
\text { Climacoptera transoxana (Iljin) Botsch., Ferula foetida (Bunge) Regel. }\end{array}$ \\
\hline 3 & $\begin{array}{l}\text { Fall and } \\
\text { winter }\end{array}$ & $\begin{array}{l}\text { Peganum harmala L., Artemisia terrae-albae Krasch., Ferula foetida (Bunge) Regel, Bromus tectorum L., Astragalus villosissimus Bunge, } \\
\text { Haloxylon persicum Bunge ex Boiss.\& Buhse, Haloxylon ammodendron (C. A. Mey.) Bunge, Climacoptera transoxana (Iljin) Botsch., } \\
\text { Halocnemum strobilaceum (Pall.) Bieb., Triticum vulgare L., Zea mays L., Glycyrrhiza glabra L., Alhagi pseudalhagi (Bieb.) Fisch.), } \\
\text { Halostachys belangeriana (Moq.)Botsch., Elaeagnus orientalis L., E. oxycarpa Schlecht. }\end{array}$ \\
\hline
\end{tabular}


average values of all components decreased from December to February and had a tendency to grow from June to August. This finding suggests a seasonal variation in the available food supply. Table 1 also indicated that the content of protein and fat were higher in comparison with the average amount of components of camel milk which were described in the study [4].
In this aspect, it should be noted that camel milk is enriched with various protective proteins such as lysozyme, lactoferrin, lactoperoxidase, peptidoglycan recognition proteins, and immunoglobulin $\mathrm{G}$ and $\mathrm{A}$ which exert antibacterial, antiviral, antifungal and antiphrastic activity, immunological properties, growth promotion activity, and anti-tumor activity [16]. Another point is

Table 3 The wild-growing plants with medicinal properties in food supply of camels

\begin{tabular}{|c|c|c|c|c|}
\hline № & Latin name & Local name & Vegetation period & Application in traditional medicine \\
\hline 1 & Alhagi pseudalhagi (M. Bieb.) Fisch. & Jantak & May-June, July-August & Blood-forming organs and gastrointestinal tract \\
\hline 2 & Ammodendron conollyi Bunge ex Boiss. & Qoyan suyek & April-May, October & Respiratory system \\
\hline 3 & Artemisia terrae-albae Krasch. & Zhoosan & $\begin{array}{l}\text { May-September, } \\
\text { October }\end{array}$ & Gastrointestinal tract \\
\hline 4 & Artemisia vulgaris $\mathrm{L}$. & Shuvoq & May-September & $\begin{array}{l}\text { Atherosclerosis, anemia, gastrointestinal tract } \\
\text { stomach ulcer, at epilepsy, neurasthenia, } \\
\text { nervous insomnia, and alkologolizm }\end{array}$ \\
\hline 5 & Asparagus inderiensis F.K. Blum ex Pacz. & Shop & May-June, July-August & Rheumatism \\
\hline 6 & Atriplex aucheri Moq. & Oshe, alabuta & June, August & Gastrointestinal tract and urogenital system \\
\hline 7 & Atriplex dimorphostegia Kar. \& Kir. & Shop & April-May, June-July & Laxative remedy \\
\hline 8 & Bassia hyssopifolia (Pall.) Kuntze & Shop & May-June, August & Dermatological problems \\
\hline 9 & Calligonum aphyllum (Pall.) Guerke & Qizil juzgun & May, June & Gastrointestinal tract \\
\hline 10 & Calligonum caput-medusae Schrenk & Narjuzgun & May, July & Gardiovascular system \\
\hline 11 & Carex physodes M. Bieb. & Ren & March, April-June & Cardiovascular and gynecological diseases \\
\hline 12 & $\begin{array}{l}\text { Consolida camptocarpa (Fisch. \& C.A. Mey.) } \\
\text { Nevski }\end{array}$ & Shop & May, June-July & Cardiovascular system \\
\hline 13 & Convolvulus hamadae (Vved.) Petrov & Aq peshek & April-May, July-October & Gastrointestinal tract \\
\hline 14 & Cynodon dactylon (L.) Pers. & Azhiriq & July, August & Oncology \\
\hline 15 & Ferula foetida (Bunge) Regel & Sasiq geuerek & May-August & $\begin{array}{l}\text { Gastrointestinal tract, respiratory system and } \\
\text { cancer }\end{array}$ \\
\hline 16 & Glycyrrhiza glabra L. & Boyan & June-August & Gastrointestinal tract and respiratory system \\
\hline 17 & Halostachys belangeriana (Moq.) Botsch. & Qarabaraq & July-October & Hypotension \\
\hline 18 & Haloxylon aphyllum (Minkw.) Iljin & Qara sexeul & May-October & $\begin{array}{l}\text { Cardiovascular disease, hypertension, and } \\
\text { blood disorders }\end{array}$ \\
\hline 19 & Heliotropium acutiflorum Kar. \& Kir. & Shop & May, June & Blood-forming organs \\
\hline 20 & Lachnoloma lehmannii Bunge & Shop & April, May & Cardiovascular system \\
\hline 21 & Limonium otolepis (Schrenk) Kuntze & Kermek & April-June, September & Gastrointestinal tract and oral cavity \\
\hline 22 & Medicago lupulina L. & $\begin{array}{l}\text { Zhabayi } \\
\text { zhonyshka }\end{array}$ & May, June & Blood-forming organs \\
\hline 23 & Salicornia europaea L. & Shor sora & June, July & Urinogenital system and oncology \\
\hline 24 & Salsola arbuscula Pall. & Boyalysh & $\begin{array}{l}\text { May-June, September- } \\
\text { October }\end{array}$ & Cardiovascular system and gastrointestinal tract \\
\hline 25 & Salsola dendroides Pall. & $\begin{array}{l}\text { Karaganda, aq } \\
\text { sora }\end{array}$ & $\begin{array}{l}\text { June-July, September- } \\
\text { October }\end{array}$ & Urogenital and hematologic systems \\
\hline 26 & Salsola richteri (Moq.) Kar. ex Litv. & Aq sherkez & $\begin{array}{l}\text { April-May, September- } \\
\text { October }\end{array}$ & Cardiovascular and urogenital system \\
\hline 27 & Smirnowia turkestana Bunge & Shop & April-May, May-June & Urogenital and respiratory system \\
\hline 28 & Spergularia marina (L.) Griseb. & Shop & April-June, June & Urogenital system \\
\hline 29 & Sphaerophysa salsula (Pall.) DC. & Partyldauik & May, August & Cardiovascular system \\
\hline 30 & Suaeda altissima (L.) Pall. & Shop & June, August & Cardiovascular system \\
\hline
\end{tabular}


peptides in camel milk. Camel's peptide hormone, insulin, does not form coagulum in the acids environment of the stomach like the insulin of other mammals and has a good potential and helps in the reduction of insulin requirement in type I diabetic patients [17]. Regarding the fat content, it should note that the average diameter of fat globules in camel milk is three times less than that in buffalo milk. It indicates a high state of dispersion of fat in milk and is more digestible for humans [18].

Analysis of the dispersion of the values found for component composition among camel milk samples proposed influence of various factors such the health status, herd management practices, environmental conditions, and food supply. All mentioned factors are interconnected and probably food supply plays the most important role and can explain the particular richness of camel milk.

The obtained data of a poll of owners of camels and shepherds revealed that camels are grazed in extensive territories from March to October feeding on the wild-growing plants and constantly moved from one place to another. Plant diversity of available fodder flora, growing in the investigated period, showed that the fodder base consists of around 300 plants. Table 2 shows plants in the main diet of camels on seasons. Analysis of plant species revealed that 30 plants are widely used in traditional medicine.

Table 3 shows the wild-growing herbs with healing properties in the food supply of camels. The presented plants cover a wide range of medicinal properties which are applied for the treatment of the cardiovascular diseases, diseases of the digestive tract, respiratory, urogenital and hematologic systems, and others, since ancient time in traditional medicine. Among them are Artemisia terrae-albae Krasch., Salsola richteri (Moq.) Kar. ex Litv., Smirnowia turkestana Bunge, Ferula foetida (Bunge) Regel, Alhagi pseudalhagi (Bieb.) Fisch., Halostachys belangeriana (Moq.) Botsch. which are included in the main diet and that one makes more than $80 \%$ of the food supply which are eaten by camels (Figs. 3, 4, and 5). The historical experience of application of these plants in traditional medicine is confirmed by many investigations which are directed on the discovery of the bioactive compounds. Some phytochemicals with helpful cardiovascular effects have been isolated from Ferula species [19]. Alhagi pseudalhagi (Bieb.) Fisch. is used as a remedy for rheumatic pains, various types of gastrointestinal discomforts, urinary tract diseases, and liver diseases [20]. Aqueous extract of Cynodon dactylon (L.) Pers. exerted its good capability for wound healing activity [21]. Immunomodulatory and antioxidant activities were found by using Artemisia vulgaris L. [22, 23]. The medicinal properties of other presented plants in Table 3 were also described in our previous studies [11, 12]. These plant species and their bioactive agents with therapeutic properties could be secreted in milk and milk-based products. It can be seen as one of the points of the health benefit of camel milk [24]. On the other hand, these plants can have an influence on the health

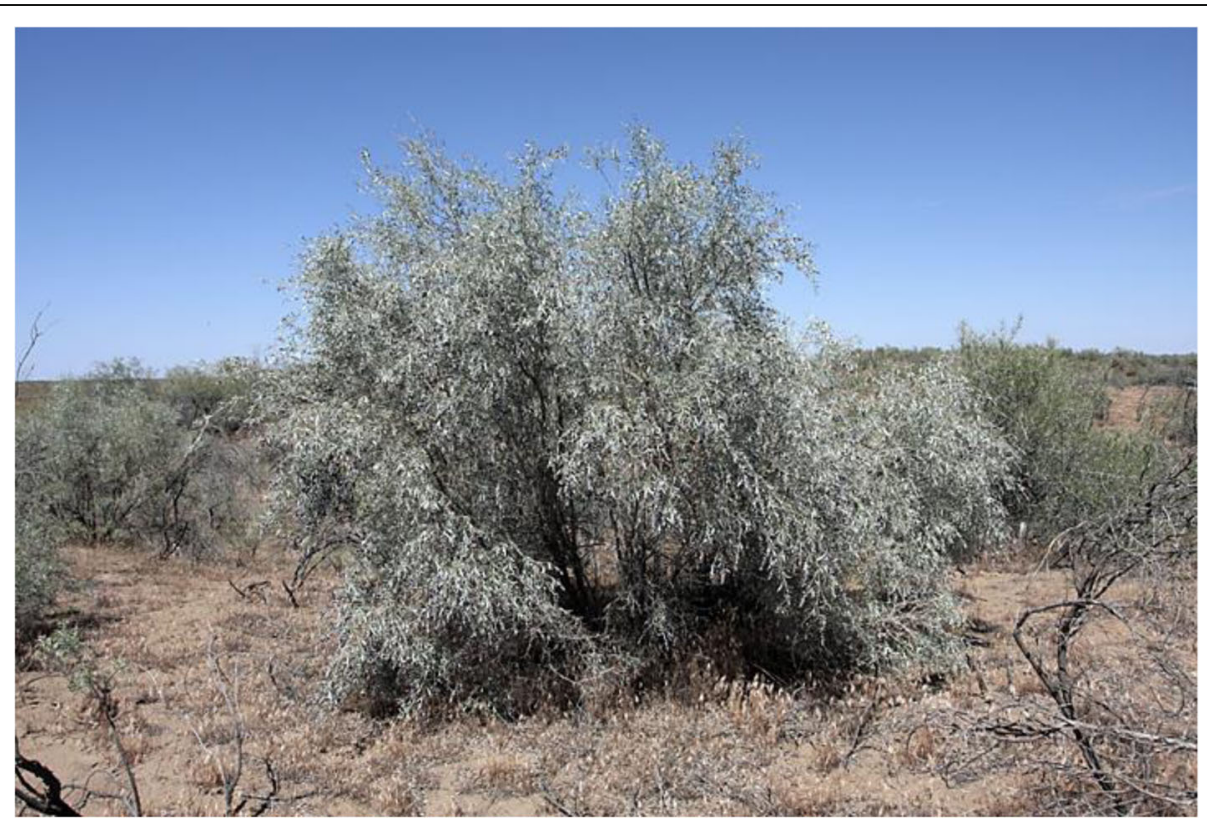

Fig. 3 Ammodendron conollyi Bunge ex Boiss. blooms in April and fructifies in May. Picture taken in May 2017, in Kyzylkum Desert. In traditional medicine, it is used for a treatment of respiratory system. Roots of sand acacia have traditionally been used by the local population to color wool by yellow. Wood is used as fuel and this plant is a good anchor for sand 


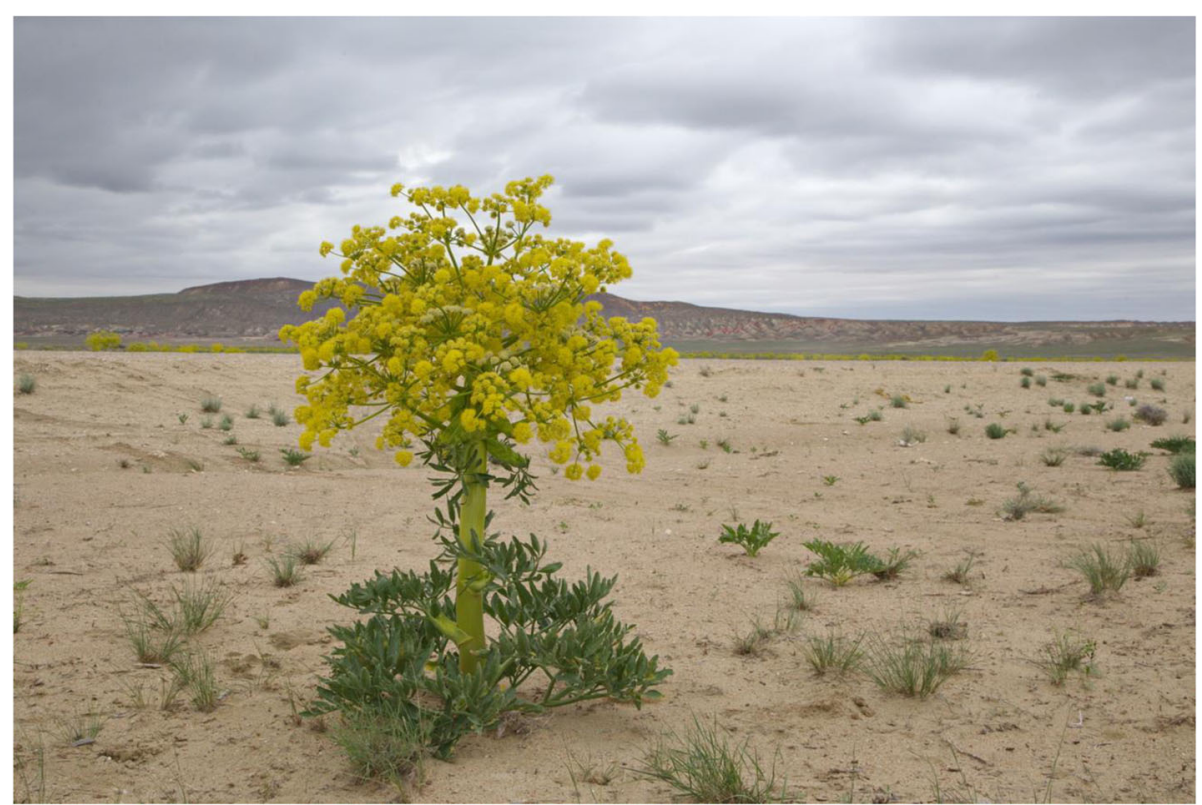

Fig. 4 Ferula foetida (Bunge) Regel, blooms in April-May and fructifies from May to June. Picture taken in June 2017, in Kyzylkum Desert. Ferula foetida (Bunge) Regel has an application as a remedy against the gastrointestinal tract and respiratory system problems in traditional medicine. By interview of healers, it was revealed the milled young ferula shoots and its mix with acidic milk are used to treat tumors and syphilis. Alcohol tincture of ferula resin and emulsions are used in the treatment of asthma, convulsions, and nervous diseases.

status of camels, and therefore, on the composition of camel milk as well.

\section{Conclusion}

The results of the current study showed the particular richness of camel milk in protein and fat content.
Analysis of plants in main diet of camels revealed the presence of the wild-growing plants with medicinal properties. This finding suggests that the healing benefit of camel milk can be connected with content of the various protective proteins and secretion of the bioactive compounds from plants with medicinal properties via

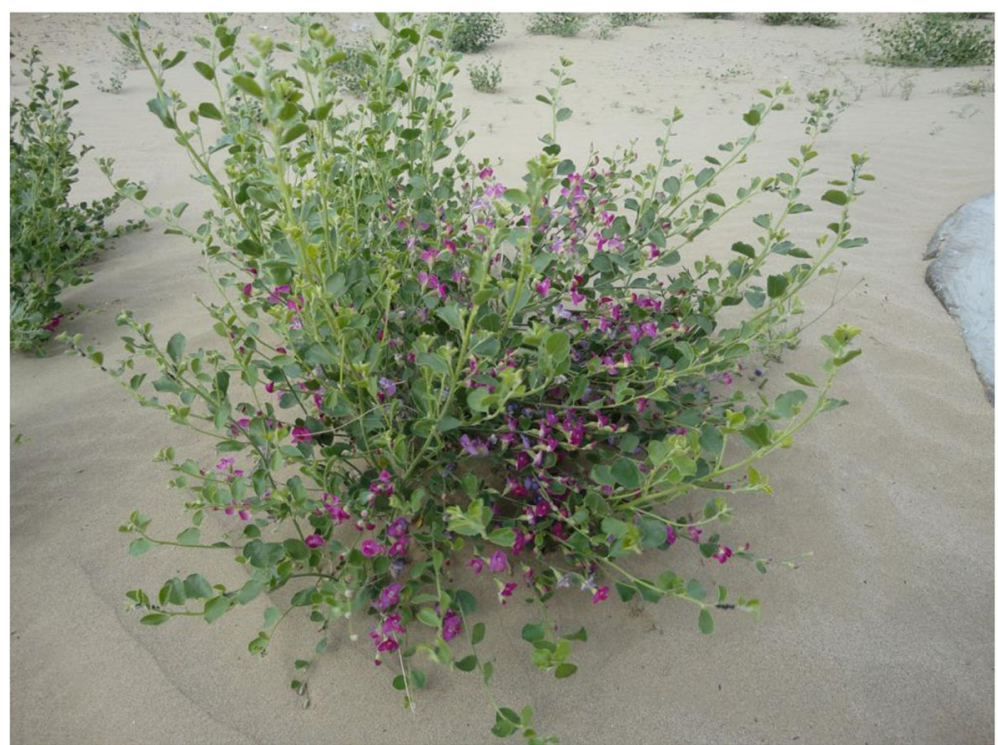

Fig. 5. Smirnowia turkestana Bunge. The plant blooms between April and May, a period of fruiting between May and June. The plant was photographed in May 2017, on the sands of Kyzylkum. In traditional medicine, Smirnowia turkestana Bunge is used as a remedy for treatment of urogenital and respiratory system 
food. Undoubtedly, other factors such as the geographical origin, physiological stage, and seasonal variations have an influence on the composition of camel milk and its properties.

Camel milk and its based products have a long-time tradition as a dairy food with healing properties in Uzbekistan. More investigations are still required for understanding the healing benefit of camel milk on human. The above reported information suggests a good perspective in development of the food market in Uzbekistan based on camel milk.

\section{Abbreviation \\ AOAC: Association of Official Analytical Chemists}

\section{Acknowledgements}

Not applicable

\section{Authors' contributions}

WP contributed $50 \%$ of the work. OKK contributed $30 \%$ of the work. GJA contributed $10 \%$ of the work. EBM contributed 10\% of the work. All author read and approved the final manuscript.

\section{Funding}

Not applicable

\section{Availability of data and materials}

Herbarium samples deposited in Central Herbarium (TASH) of Institute of the Botany, Academy of Sciences Republic of Uzbekistan.

Herbarium № RR 122 16/04/2016 - RR 175 23/06/2016

№ RR_ 243 04/08/2016 - RR_ 267 27/09/2016

Herbarium № RR_ 321 23/03/ 2017 - RR_ 545 15/10/2017

Herbarium № RR_615 05/04/ 2018 - RR_ 660 15/10/2018

\section{Competing interests}

The authors declare that they have no competing interests.

\section{Author details}

'Department of Organic Synthesis, Institute of the Chemistry of Plant Substances, Building 77, Acad. Kh. Abdullaev Str., Tashkent, Uzbekistan 100170. ${ }^{2}$ Laboratory of Plant Resources, Institute of the Botany, Academy of Sciences of the Republic of Uzbekistan, Durmon Yuli 32, Mirzo Ulugbek district, Tashkent, Uzbekistan 100125. ${ }^{3}$ Laboratory of Plant Ecology, Institute of Natural Sciences of Karakalpak Branch of Academy of Sciences of the Republic of Uzbekistan, Berdakh Str. 41, Nukus, Uzbekistan 230100.

${ }^{4}$ Department of Biotechnology, Tashkent Chemical Technological Institute The Ministry of Higher and Secondary Specializer Education, Building 32, Navoi Str. Tashkent, Uzbekistan 100011.

Received: 28 June 2019 Accepted: 21 November 2019

Published online: 06 December 2019

\section{References}

1. Abdel GM, Abdel G, Alhaider AA. The unique medicinal properties of camel products: a review of the scientific evidence. J Taibah Univ Med Sci. 2016; 11:98-103.

2. Dirar HA. The indigenous fermented foods of the Sudan: a study in African food and nutrition. Waillingford: CAB; 1993. p. 303-44.

3. Kumar YK, Rakesh K, Lakshmi P, Jitendra S. Composition and medicinal properties of camel milk: a review. Asian J Dairy Food Res. 2015:34:83-91.

4. Al Haj OA, Al Kanhal HA. Compositional, technological and nutritional aspects of dromedary camel milk. Int Dairy J. 2010;20:811-21.

5. Asresie A, Yusuf M. Traditional consumption, therapeutic value and its derived dairy products of dromedary camel (Camelus Dromedaries) milk in Somali Regional State, Eastern Ethiopia. Adv Life Sci Technol. 2014;26:48-52.

6. Khalil IE, Muhammad HA, Hana AA, Inteaz A, Taha R. Comparison and characterization of fat and protein composition for camel milk from eight Jordanian locations. Food Chem. 2011;127:282-9.
7. Hadef L, Aggad H, Hamad B, Saied M. Study of yield and composition of camel milk in Algeria. Sci Sdudy Res: Chem Chem Engin Biotech Food Ind. 2019;19:1-11.

8. Benkerroum N, Boughdadi A, Bennani N, Hidane K. Microbiological quality assessment of Moroccan camel's milk and identification of predominating lactic acid bacteria. World J Microbiol Biotechnol. 2003;19:645-8.

9. Konuspayeva G, Jurjian S, Gerard Loiseau G, Barci V, Akhmetsadykova S, Meldebekova AA, Faye B. Contamination of camel milk (heavy metals, organic pollutants and radionuclides) in Kazakhstan. J Environ Protect. 2011;2:90-6.

10. Konuspayeva G, Faye B, Loiseau G. The composition of camel milk: a metaanalysis of the literature data. J Food Compos Anal. 2009;22:95-101.

11. Abdiniyazova JG, Khojimatov OK, Pak W. Honey in traditional cuisine of Uzbekistan and analysis of melliferous flora of Karakalpakstan. J Ethnic Food. 2016;3:1-6.

12. Khojimatov OK, Abdiniyazova JG, Pak W. Some wild growing plants in traditional foods of Uzbekistan. J Ethnic Food. 2015:2:25-8.

13. AOAC International. Official Methods of Analysis, 18th edn, 2005. Gaithersburg: AOAC International; 2007.

14. Haddadin MSY, Gammoh SI, Robinson RK. Seasonal variations in the chemical composition of camel milk in Jordan. J Dairy Res. 2008;75:8-12.

15. Yagi $R$, Etzion Z. Effect of drought condition on the quality of camel milk. J Dairy Res. 1980;1980(47):159-66.

16. Mona EY, Ragia OM, Abeer AKH, Mosa TE. Biochemical effects of fermented camel milk on diarrhea in rats. NY Sci J. 2010;3:106-11.

17. Agrawal RP, Jain S, Shah S, Chopra A, Agarwal V. Effect of camel milk on glycemic control and insulin requirement in patients with type 1 diabetes: 2-years randomized controlled trial. Eur J Clin Nutr. 2011;65:1048-52.

18. D'Urso S, Cutrignelli MI, Calabrò S, Bovera F, Tudisco R, et al. Influence of pasture on fatty acid profile of goat milk. J Anim Physiol Anim Nutr (Berl). 2008:92:405-10.

19. Safaeian L, Ghannadi A, Javanmard SH, Vahidian MH. The effect of hydroalcoholic extract of Ferula foetida stems on blood pressure and oxidative stress in dexamethasone-induced hypertensive rats. Res Pharm Sci. 2015;10:326-34.

20. Srivastava B, Sharma H, Dey YN, Wanjari MM, Jadhav AD. Alhagi pseudalhagi: a review of its phyto-chemistry, pharmacology, folklore claims and Ayurvedic studies. Int J Herbal Med. 2014;2:47-51.

21. Biswas TK, Pandit S, Chakrabarti S, Banerjee S, Poyra N, Seal T. Evaluation of Cynodon dactylon for wound healing activity. J Ethnopharmacol. 2017;197:128-37.

22. Temraz A, Walid T. Characterization of antioxidant activity of extract from Artemisia vulgaris. Pak J Pharm Sci. 2008;21:321-6.

23. Marbun $R$, Suwarso $E$, Yuandani $Y$. Immunomodulatory effects of ethanol extract of Artemisia vulgaris L. in male rats. Asian J Pharm Clin Res. 2018;11:245-7.

24. Kula JT, Tegeng D. Chemical composition and medicinal values of camel milk. Adv Life Sci Technol. 2016:43:1-11.

\section{Publisher's Note}

Springer Nature remains neutral with regard to jurisdictional claims in published maps and institutional affiliations.

Ready to submit your research? Choose BMC and benefit from:

- fast, convenient online submission

- thorough peer review by experienced researchers in your field

- rapid publication on acceptance

- support for research data, including large and complex data types

- gold Open Access which fosters wider collaboration and increased citations

- maximum visibility for your research: over $100 \mathrm{M}$ website views per year

At BMC, research is always in progress.

Learn more biomedcentral.com/submissions 